\title{
Oksana Bulvinska
}

ORCID iD 0000-0002-6764-4340

$\mathrm{PhD}$ (Pedagogy), Senior Researcher, Senior Researcher of Scientific-Research Laboratory of Educology, Borys Grinchenko Kyiv University, 13-b Tymoshenko Str., 04212 Kyiv, Ukraine, o.bulvinska@kubg.edu.ua

Nataliia Khanykina

ORCID 0000-0002-5920-9779

$\mathrm{PhD}$ (Philology), Senior Researcher of Scientific-Research Laboratory of Educology, Borys Grinchenko Kyiv University, 13-b Tymoshenko Str., 04212 Kyiv, Ukraine, n.khanykina@kubg.edu.ua

\section{INTERACTIVE METHODS IN COMMUNICATIVE EDUCATION}

The article deals with the problem of using of interactive methods and forms of teaching, which are based on mutual learning, and community education. The empirical material of the research was collected by the method of questioning of academic staff from Ukrainian universities. The respondents were asked questions, grouped in 2 blocks. In the first block, the respondents had to pick up the interactive methods, which they use in teaching. The second block was a question about of the effectiveness of interactive methods. The results of the study made it possible to conclude that lecturers of Ukraine's higher education institutions use interactive methods and forms of teaching for the communicative skills and competencies development, developing communicative personality traits and accumulation of professional and communicative experience, but their choice is not diverse and there is a lack of teachers' knowledge about interactive methods and forms of teaching. These results contradict modern educational trends, which imply the activation, stimulation and encouragement of the activity of each student in the educational process.

Key words: academic staff; communicative education; interactive methods and forms; learning; teacher; teaching.

https://doi.org/10.28925/1609-8595.2019.4.6873

Introduction. Modern philosophy of education emphasizes adoption and expansion of communicative education in educational environment. The report of the National Communication Association (USA) in 2003 got the name of «Communication in the General Education Curriculum: A Critical Necessity for the 21st Century» (2004).

In 2007, continuing research in 2000, Sh. P. Morreale and J. Pearson have analyzed 93 scientific publications, which demonstrated the importance of the study of communication. Six themes that provide evidence of the importance of communication instruction in the 21st century emerged from the thematic analysis of the 93 annotated references (Morreale, Pearson, 2008, p. 225):

1. development of the whole person (10 references);

2. improvement of the educational enterprise (19 references);

3 . being a responsible participant in the world, socially and culturally (6 references);

4. succeeding as an individual in one's career and in business (23 references);

5. enhancing organizational processes and organizational life (24 references);

6 . emerging concerns in the 21st century (11 references focused on health communication, crisis and communication, crime and policing).
Consequently, communicative education at all levels of the education system improves the quality of the professional education and helps individuals succeed in their careers and in business but also have the potential to improve the quality of communication in society.

Communicative education is a process of acquiring communicative knowledge, forming communicative skills and competencies, developing communicative personality traits and accumulation of professional and communicative experience in research interaction with individuals and groups, which are required of future professionals for finding ways of solving professional problems, information sharing and collective evaluation of the work. It should be noted that communicative education has an applied nature, that is, it aims to prepare students for solving specific communication problems in professional situations. «Valuable ideal of communicative education and education is a person and a specialist who actively creates a communicative culture around him, a person who can work with different social and personal meanings, is able to enter into a dialogue and to be in dialogue, a person oriented to the Other» (Matyash, 2014).

In past studies based on the analysis of curriculum documents of universities, as well as publications of national and foreign researchers, three strategic directions of communicative education were revealed: 1) specialized programs for undergraduate, graduate and $\mathrm{PhD}$ level of communication (Communication Science 
or Communication Studies); 2) introduction to the curriculum of basic courses in communication obligatory for specialists in various fields; 3 ) education based on the principles of communicative didactics (Bulvinska, 2016, p. 12-14). The aim of the present study is researching the use of the interactive methods and forms in the communicative education.

Interactive methods and forms in communicative education. It should be noted that the term «communicative education» has not been universally adopted, due to the fact that the education area is not yet sufficiently developed; different scientific works define for the term as «communication-oriented education», «a communicative approach in education», «education organized in a communicative way» and so on. Consequently, the conceptual framework still needs well-reasoned formation. But the meaning of the quoted definitions allows us to consider them as having the same view of a learning process as a joint purposeful activity of teacher and student that interact in terms of cooperation and partnership. Communicative didactics is not focused on the content of school discipline, but nurtures a culture of thinking instead, teaches critical thinking and reflective analysis, concerns with formation of competences. The strategic goal of communicative didactics is not encyclopaedic learning and knowledge accumulation of dead-weight, frozen, ready-made character, but gaining, formation, acquisition of knowledge here and now, in every class, in dialogue, during an intellectual interaction of all participants of the educational process. «The lesson-ritual should be replaced by a lesson, which is a communicative event for all its participants: a student, a teacher and a fellow student. In other words, communication (informal communication) and the teacher's organization of an effective understanding context should replace the informing and management (process of learning information)» (Tyupa, 2012).

The communicative way of education employs such forms and methods of teaching that would foster the process of formation and development of communicative competences, nurture communicative personal qualities and promote accumulation of professional communicative experience with the environment.

Interactive teaching methods based on interaction between students are indispensable in the process. During the interactive learning all participants of the learning process cooperate among them, exchange information, jointly solve the problems, simulate the situations, evaluate the colleagues' actions and their own behaviour, and merge in the real atmosphere of business collaboration to solve a number of problems according to their interests, needs and requests (Sysoieva, 2013, p. 56). Interactive training transforms the reciprocal actions of teacher and student: student activities come to the foreground, and teacher acts as an organizer of the learning process, provider of necessary conditions for students.

The European Commission's Tuning Project, which has been implemented in higher education since 2000 for the harmonization of educational structures in Europe, has conducted surveys among graduates of higher education institutions, lecturers and employers on the importance of some competencies for working in a specialty, as well as on how to ensure graduation universities of competencies identified on the basis of identified societal needs and projected social changes. The results of the survey showed that the most important forms and methods of learning that would promote the development of communicative competences, the participants called the following: group work, presentations, special lectures, training courses, production practice, in which students work in the workplace in the educational environment, business games (Tuning of educational structures in Europe, 2000). These results formulated the basis for developing lecturers' questionnaires from higher education institutions on interactive forms and teaching methods.

Method. The research methodology includes an analysis of questionnaires completed by university lecturers. The empirical material of the research was collected by the method of questioning with the direct participation of the author. Academic staff from the Taras Shevchenko National University of Kyiv, National University of Kyiv-Mohyla Academy, Ivan Chernyakhovsky National Defense University of Ukraine, Kyiv National University of Construction and Architecture, Kherson State University, Interregional Academy of Personnel Management, students of the Central Institute of Postgraduate Pedagogical Education of the National Academy of Educational Sciences of Ukraine, as well as scientists from the Institute of Education Content Modernization were interviewed. A total number of 68 respondents were interviewed. Among respondents there were teachers of mathematical, technical, natural and humanitarian sciences. The survey was anonymous, but we asked the respondents to name their work experience in the sphere of pedagogical activity, as well as to note the presence or absence of an academic degree. The results of the distribution of respondents with the reference to these features are presented in Figure 1 and Figure 2.

The respondents were asked questions, grouped in 2 blocks. In the first block, the respondents had to pick up the interactive methods, which they use during the time of teaching. The respondents were asked multiple choice questions with a chance to provide their own answer. The second block was a question about of the effectiveness of interactive methods.

The results of this survey, ranked by the number of responses, are presented in Table 1 (percentages are rounded to integers).

However, it should be noted that the lecturers' survey results indicate ambiguous understanding of the interactive methods effectiveness. Responses on that they should be used in certain learning situations, depending on the educational material, are twice as high as answers with a clear understanding of their effectiveness (66\% vs. $30 \%$ ). These results are inconsistent with Hattie's (2009) findings about students' activity in class and contradict modern educational trends, which imply the activation, stimulation and encouragement of the activity of each student in the educational process.

Conclusions. The results of the study made it possible to conclude that lecturers of Ukraine's higher education institutions use interactive methods and forms of teaching for the communicative skills and competencies development, developing communicative personality traits and accumulation of professional and communicative experience, but their choice is not diverse.

The perspectives of further research are seen in the foreign experience study and Ukrainian practices in communicative education. 


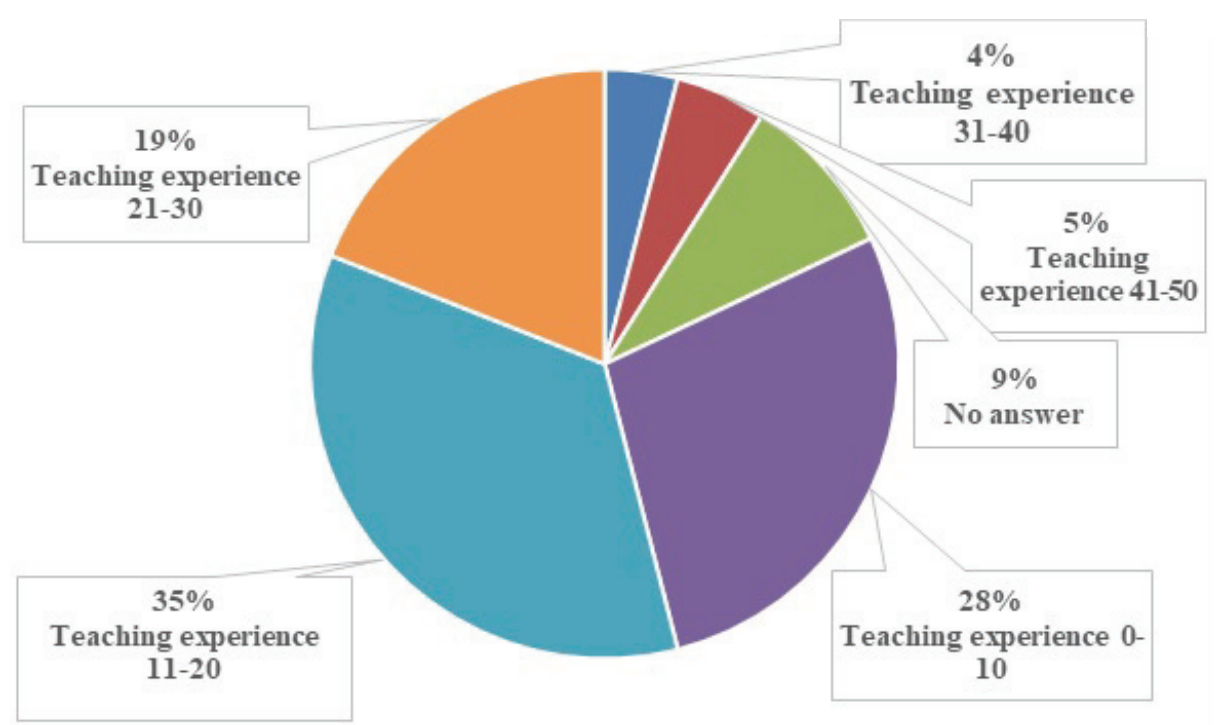

Figure 1. Duration of teaching experience of respondents

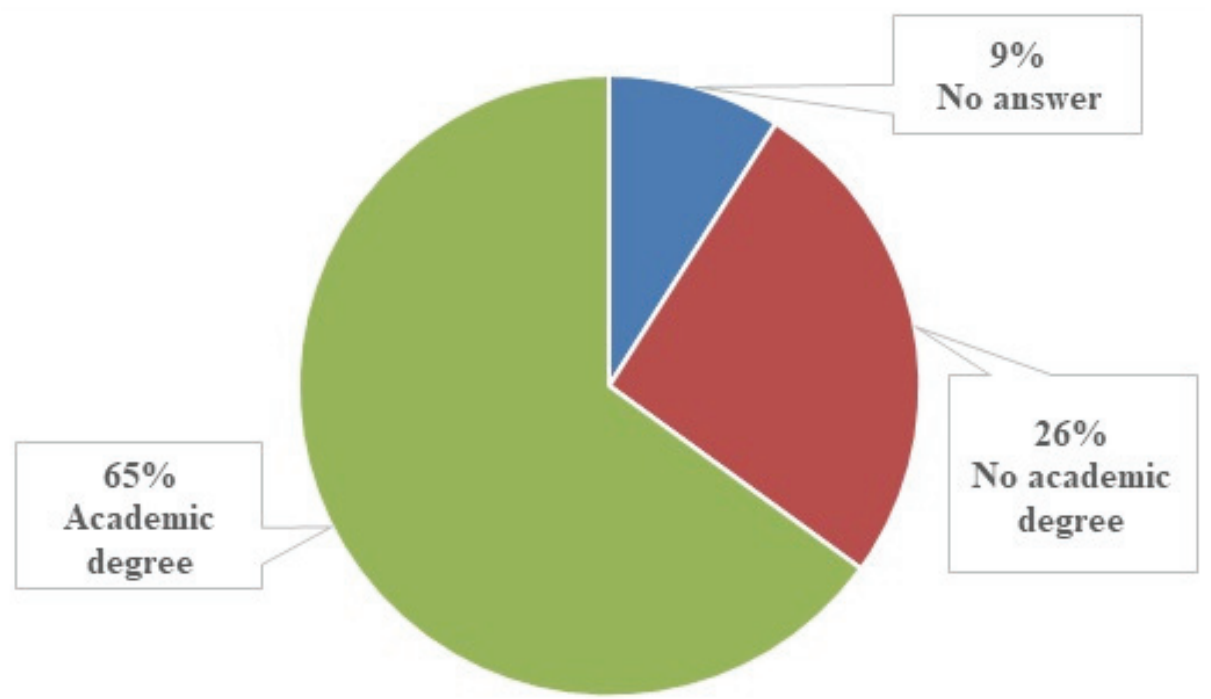

Figure 2. Respondents' academic degree

Table 1

The results of the survey on interactive methods

\begin{tabular}{|l|c|c|}
\hline \multicolumn{1}{|c|}{ Interactive methods } & $\begin{array}{c}\text { Number of } \\
\text { answers }\end{array}$ & $\%$ \\
\hline dialogue lecture & 44 & 65 \\
\hline seminar discussion & 38 & 56 \\
\hline small group training & 33 & 48,5 \\
\hline $\begin{array}{l}\text { extracurricular activity (invited guest lectures, excursions, lecture, concerts, } \\
\text { theatrical performances, films, exhibitions) with further discussion }\end{array}$ & 29 & 43 \\
\hline «brain storm» & 25 & 37 \\
\hline round-table discussion & 24 & 35 \\
\hline project method & 20 & 29 \\
\hline business game & 17 & 25 \\
\hline mutual learning & 11 & 16 \\
\hline PRES-formula (Position - Reason - Explanation or Example- Summary) & 10 & 15 \\
\hline think-pair-share & 9 & 13 \\
\hline case-study & 9 & 13 \\
\hline lecture - a press conference & 4 & 6 \\
\hline lecture with pre-planned mistakes & 3 & 5 \\
\hline other methods (name them) & 2 & 3 \\
\hline
\end{tabular}


As we see, lecturers are using actively such interactive methods as lecture-dialogue and seminar-discussion (these methods have gained more than $50 \%$ of the elections). Approximately $50 \%$ of the election work is in small groups (48.5\%) and extracurricular activity with further discussion (43\%). However, other interactive methods are less popular among university lecturers (from $37 \%$ to $3 \%$ ), which suggests some uniformity in the choice of these methods and the lack of teachers' knowledge about them. Only two respondents named other interactive methods and forms of work that they use: trainings, as well as the preparation of book trailers with their further discussion.

Therefore, it should be noted that interactive teaching methods for the development of communicative skills and competencies, developing communicative personality traits and the accumulation of professional and communicative experience used in the educational process of higher education institutions is not enough.

Our research confirms that despite new trends and signs of a shift, lectures remain absolutely the most typical way of teaching at the university, appearing in $100 \%$ of responses from respondents. Noticeably, seminars and projects are also a part of respondents learning experience, respectfully $69 \%$ and 51\%. Only one in five students report having debates, fieldwork, tutorials and workshops as a part of their learning experience (Bologna with Student Eyes, 2015).

However, the professor of the University of Auckland, John Hattie, analyzing in the book «Visible Learning» (2009) the results of a 15-year study of the causes leading to success in learning, states that students, not teachers should be talking at least $80 \%$ of a time in a classroom. Consequently, engaging students in interactive learning is a guarantee not only of the communicative competences development, but also of an effective and high-quality education in general.

Answers to the second question of our questionnaire, the quantitative summaries of which are given in Table 2, indicate that lecturers understand the interactive methods effectiveness. Nobody named them ineffective, the answers about the same effectiveness of interactive and traditional informational methods were also singular (4\%).

These results confirm V. C. Blândul's (2015) conclusions that in students' opinion, teachers are open to new, encourages communication in classroom both horizontally (student - student) and vertically (student - teacher), use cooperative learning teaching strategies, namely give support students in difficulty in successful achievement of learning tasks (p. 2572).

Table 2

\section{The results of the survey on effectiveness of interactive methods}

\begin{tabular}{|l|c|c|}
\hline \multicolumn{1}{|c|}{ The degree of effectiveness of interactive methods } & $\begin{array}{l}\text { Number of } \\
\text { answers }\end{array}$ & \% \\
\hline much more effective & 20 & 30 \\
\hline equally effective & 3 & 4 \\
\hline depending on the teaching material being taught & 45 & 66 \\
\hline completely ineffective & - & - \\
\hline Your answer option & - & - \\
\hline
\end{tabular}

However, it should be noted that the lecturers' survey results indicate ambiguous understanding of the interactive methods effectiveness. Responses on that they should be used in certain learning situations, depending on the educational material, are twice as high as answers with a clear understanding of their effectiveness (66\% vs. $30 \%$ ). These results are inconsistent with Hattie's (2009) findings about students' activity in class and contradict modern educational trends, which imply the activation, stimulation and encouragement of the activity of each student in the educational process.
Conclusions. The results of the study made it possible to conclude that lecturers of Ukraine's higher education institutions use interactive methods and forms of teaching for the communicative skills and competencies development, developing communicative personality traits and accumulation of professional and communicative experience, but their choice is not diverse.

The perspectives of further research are seen in the foreign experience study and Ukrainian practices in communicative education.

\section{References}

Blândul, V. C. (2015). The Role and Status of Didactic Communication in Educational Activity. Procedia - Social and Behavioral Sciences, 191, 2568-2572. DOI: 10.1016/j.sbspro.2015.04.584 (eng).

Bologna with Student Eyes (2015). Retrieved from https://www.esu-online.org/wp-content/uploads/2016/07/ BWSE-2015-online.pdf/ (eng).

Bulvinska, O. (2016). Communication-based formation of research competence by students of USA and European universities. Aktualnye problemy sovremennoj nauki: sbornik tezisov nauchnyh rabot HIII Mezhdunarodnoj nauchno-prakticheskoj konferencii (Moskow - Astana - Kharkov - Veinna, 28 oktyabrya 2016 goda) (pp.12-18). Moskow, Russia: Mezhdunarodnyj nauchnyj centr (eng).

Communication in the General Education Curriculum: A Critical Necessity for the 21st Century (2004). Washington, D. C., USA: National Communication Association (eng).

Hattie, J. A. C. (2009). Visible Learning. A synthesis of over 800 meta-analyses relating to achievement. New York, USA: Routledge (eng).

Morreale, Sh. P., Pearson, J. (2008). Why Communication Education is Important: The Centrality of the Discipline in the 21st Century. Communication Education, 57 (2), 224-240. DOI: 10.1080/03634520701861713 (eng). 
Sysoieva, S. (2013). The concepts: interactive learning for adult learners. Continuing Professional Education: Theory and Practice, 3-4, 55-59 (eng).

Matyash, O. I. (2014). O neobhodimosti vvedeniya kommunikativnyh kursov i programm v rossijskih vuzah i o roli professionalnogo soobshestva [Toward implementing communicative curricula in russian universities and the role of the professional community]. Vestnik Novosibirskogo gosudarstvennogo universiteta, 13 (6), 62-69 (rus).

Proekt TYuNING - garmonizaciya osvitnih struktur u Yevropi [Tuning of educational structures in Europe] (2000). Retrieved from http://www.unideusto.org/tuningeu/images/stories/documents/General_Brochure_Ukrainian version.pdf (ukr).

Tyupa, V. (2012). Kommunikativnye parametry uroka v shkole konvergentnoj pedagogiki [Communicative lesson parameters in the school of convergent pedagogy]. Universum: Vestnik Gercenovskogo universiteta, 1, 56-66 (rus).

\section{Література}

Blândul V. C. The Role and Status of Didactic Communication in Educational Activity. Procedia - Social and Behavioral Sciences. 2015. № 191. P. 2568-2572. DOI: 10.1016/j.sbspro.2015.04.584

Bologna with Student Eyes. 2015. URL: https://www.esu-online.org/wp-content/uploads/2016/07/BWSE-2015online.pdf/ (дата звернення: 1.11.2019).

Bulvinska O. Communication-based formation of research competence by students of USA and European universities. Актуальные проблемы современной науки: сборник тезисов научных работ ХІІІ Международной научно-практической конференции (Москва - Астана - Харьков - Вена, 28 октября 2016 года). Москва: Международный научный центр, 2016 . С. 12-18.

Communication in the General Education Curriculum: A Critical Necessity for the 21st Century. Washington, D. C.: National Communication Association, 2004. $41 \mathrm{c}$.

Hattie J. A. C. Visible Learning. A synthesis of over 800 meta-analyses relating to achievement. New York: Routledge, 2009. $382 \mathrm{c}$.

Morreale Sh. P., Pearson J. Why Communication Education is Important: The Centrality of the Discipline in the 21st Century. Communication Education. 2008. № 57 (2). P. 224-240. DOI: 10.1080/03634520701861713.

Sysoieva S. The concepts: interactive learning for adult learners. Неперервна професійна освіта: теорія $i$ практика. 2013. № 3-4. Р. 55-59.

Матьяш О. И. О необходимости введения коммуникативных курсов и программ в российских вузах и о роли профессионального сообщества. Вестник Новосибирского государственного университета. 2014. Т. 13. Вып. 6. С. $62-69$.

Проект ТЬЮНІНГ - гармонізація освітніх структур у Європі. URL: http://www.unideusto.org/tuningeu/ images/stories/documents/General_Brochure_Ukrainian_version.pdf (дата звернення: 01.11.2019).

Тюпа В. Коммуникативные параметры урока в школе конвергентной педагогики. Universum: Вестник Гериеновского университета. 2012. № 1. С. 56-66.

\section{ІНТЕРАКТИВНІ МЕТОДИ В КОМУНІКАТИВНІЙ ОСВІТІ}

Бульвінська Оксана,

кандидат педагогічних наук, старший науковий співробітник,

старший науковий співробітник науково-дослідної лабораторії освітології,

Київський університет імені Бориса Грінченка,

вул. Тимошенка, 13-б, 04212 Київ, Україна, o.bulvinska@kubg.edu.ua

Ханикіна Наталія,

кандидат філологічних наук,

старший науковий співробітник науково-дослідної лабораторії освітології,

Київський університет імені Бориса Грінченка,

вул. Тимошенка, 13-б, 04212 Київ, Україна, n.khanykina@kubg.edu.ua

У статті розглядається проблема використання активних методів і форм навчання $і$ викладання, які засновані на взаємодіі між учнями, у комунікативній освіті. Комунікативна освіта розуміється як процес формування комунікативних знань, умінь, компетентостей, розвиток комунікативних якостей особистості і накопичення професійно-комунікативного досвіду взаємодії з оточуючими, які потрібні фахівщеві для успішної професійної діяльності в сощіокультурному середовищі. Емпіричний матеріал дослідження був зібраний методом опитування науково-педагогічних працівників з українських університетів. Респондентам були запропоновані питання, згруповані у 2 блоки. У першому блоці опитані мали вибрати інтерактивні методи, що використовуються ними в освітньому процесі. Другий блок був присвячений розумінню ефективності інтерактивних методів.

Результати дослідження підтвердили: незважаючи на нові освітні тенденції, викладачі недостатньо використовують в освітньому процесі інтерактивні методи $i$ форми (за винятком лекції-діалогу $i$ семінару-дискусії). Інші інтерактивні методи менш популярні серед викладачів університетів, що свідчить про деяку одноманітність у виборі цих методів і недостатню обізнаність викладачів про них. Результати опитування науково-педагогічних працівників свідчать також про неоднозначне розуміння ефективності інтерактивних методів. Відповідей про те, що їх слід використовувати в певних навчальних ситуаціях, в залежності від навчального матеріалу, вдвічі більше, ніж відповідей з однозначним розумінням 
їх ефективності. Ці результати не відповідають сучасним освітнім тенденціям, які передбачають активізацію, стимулювання та заохочення активної діяльності кожного студента в освітньому процесі.

Ключовіслова:викладання; викладач; інтерактивніметодиі форми; комунікативна освіта; навчання; науково-педагогічні працівники.

\title{
ИНТЕРАКТИВНЫЕ МЕТОДЫ В КОММУНИКАТИВНОМ ОБРАЗОВАНИИ
}

\author{
Бульвинская Оксана, \\ кандидат педагогических наук, старший научный сотрудник, \\ старший научный сотрудник научно-исследовательской лаборатории освитологии, \\ Киевский университет имени Бориса Гринченко, \\ ул. Тимошенко, 13-б, 04212 Киев, Украина, o.bulvinska@kubg.edu.ua \\ Ханыкина Наталия, \\ кандидат филологических наук, \\ старший научный сотрудник научно-исследовательской лаборатории освитологии, \\ Киевский университет имени Бориса Гринченко, \\ ул. Тимошенко, 13-б, 04212 Киев, Украина, n.khanykina@kubg.edu.ua
}

В статье рассматривается проблема использования активных методов и форм обучения и преподавания, основанных на взаимодействии между учениками, в коммуникативном образовании. Коммуникативное образование понимается как процесс формирования коммуникативных знаний, умений, компетентостей, развитие коммуникативных качеств личности и накопления профессиональнокоммуникативного опыта взаимодействия с окружающими, которые нужны специалисту для успешной профессиональной деятельности в социокультурной среде. Эмпирический материал исследования был собран методом опроса научно-педагогических работников из украинских университетов. Респондентам были предложены вопросы, сгруппированные в 2 блока. В первом блоке опрошенные должны были выбрать интерактивные методы, используемые ими в образовательном процессе. Второй блок был посвящен пониманию эффективности интерактивных методов.

Результаты исследования подтвердили: несмотря на новые образовательнье тенденции, преподаватели недостаточно используют в образовательном процессе интерактивные методы и формь (за исключением лекиии-диалога и семинара-дискуссии). Другие интерактивные методы менее популярны среди преподавателей университетов, свидетельствует о некоторое однообразие в выборе этих методов и недостаточной осведомленности преподавателей о них. Результать опроса научно-педагогических работников свидетельствуют также о неоднозначном понимании әффективности интерактивных методов. Ответов о том, что их следует использовать в определенных учебных ситуация х, в зависимости от учебного материала, вдвое больше, чем ответов с однозначным пониманием их эффективности. Эти результаты не соответствуют современным образовательным тенденциям, которые предусматривают активизацию, стимулирование и поощрение активнойдеятельности каждого студентав образовательном проиессе.

Ключевые слова: интерактивные методы и формы; коммуникативное образование; научнопедагогические работники; обучение; преподавание; преподаватель. 